\title{
System development for production of black soldier fly larvae (Hermetia illucens) in
}

\author{
small scale, using wild flies
}

\author{
Desenvolvimento de um sistema para produção de larvas da mosca soldado negra (Hermetia \\ illucens) em pequena escala, com uso de moscas selvagens \\ Desarrollo de un sistema para la producción de larvas de mosca soldado negra (Hermetia illucens)
}

en pequeña escala, utilizando moscas salvajes

Received: 12/14/2021 | Reviewed: 12/19/2021 | Accept: 12/24/2021| Published: 01/04/2022

Sandro Morais dos Santos

ORCID: https://orcid.org/0000-0002-3816-3804 Universidade Federal de Minas Gerais, Brazil

E-mail: sandromoraisbio@gmail.com

Paolo Lages Sequenzia

ORCID: https://orcid.org/0000-0002-5707-6941

Faculdade Presidente Antônio Carlos, Brazil

E-mail: plsequenzia@gmail.com

Elias Barbosa Rodrigues

ORCID: https://orcid.org/0000-0003-4837-8961 Universidade Federal de Minas Gerais, Brazil

E-mail: eliasbrufmg@gmail.com

Isabela Parolis Martins

ORCID: https://orcid.org/0000-0001-7717-2431 Universidade Federal de Minas Gerais, Brazil

E-mail: isabelaparolis@gmail.com

Arlen Nicson Lopes Pena

ORCID: https://orcid.org/0000-0001-7817-7170 Universidade Federal de Minas Gerais, Brazil

E-mail: nicsonlopes1547@gmail.com

Diego Vicente da Costa

ORCID: https://orcid.org/0000-0001-7096-396X Universidade Federal de Minas Gerais, Brazil E-mail: diego@zootecnista.com.br

Wedson Carlos Lima Nogueira

ORCID: https://orcid.org/0000-0001-7378-780X

Universidade Federal de Minas Gerais, Brazil

E-mail: wedsonlima3@yahoo.com.br

\begin{abstract}
Technological innovation in rural areas guarantees the maintenance and subsistence of rural producers. Additionally, it is mandatory to use strategies aimed at reducing costs in animal production and reducing the environmental impact involved, making it challenging in the current global scenario. Thus, it is necessary to develop new alternative methods of production aimed at small scales, which can be implemented in small properties with reduced capital investment. In this sense, the objective was to describe the development of a system capable of inducing the production of black soldier fly larvae-BSFL (Hermetia illucens) through the attractiveness of egg laying of wild adults. To make the larvae production system, the following were needed: a plastic drum, with a capacity of 200 liters, 10 meters of $8 \mathrm{~mm}$ silk rope, $1.5 \mathrm{~m}^{2}$ of wire mesh with $25 \mathrm{~mm} \times 20 \mathrm{~mm}$ mesh, $1 \mathrm{~m}^{2} 3 \mathrm{~mm} \times 2 \mathrm{~mm}$ nylon mesh, plastic faucet for draining the slurry, one meter of $20 \mathrm{~mm}$ diameter hose, two plastic containers with capacity of 20 liters for collecting the slurry and pre-pupae; besides equipment for cutting and finishing the drum. The System was supplied with organic plant material from daily household disposal, and other plant residues produced on the property. The development of this System can provide great social and economic viability, as it can be implemented in small rural properties for the treatment of organic waste. The mechanism presented good performance for the recycling of organic waste, and also for the production of BSFL, with satisfactory quantity collected daily.
\end{abstract}

Keywords: Animal feed; Production technology; Alternative food source.

\section{Resumo}

A inovação tecnológica no meio rural garante a manutenção e a subsistência dos produtores rurais. É mandatório o uso de estratégias que visem a redução de custos na produção animal e o menor impacto ambiental. Dessa forma, torna-se necessário o desenvolvimento de métodos alternativos de produção voltado para pequenas escalas, podendo ser implantado em pequenas propriedades com pouco investimento de capital. Neste sentido, objetivou-se descrever 
um sistema capaz de induzir a produção de larvas de mosca soldado negra-LMSN (Hermetia illucens) através da atratividade da postura de ovos dos adultos selvagens. Para a confecção do Sistema de produção de larvas foram necessários um tambor de plástico (200 litros); 10 metros de corda $(8 \mathrm{~mm}), 1,5 \mathrm{~m}^{2}$ de tela metálica com malha de $25 \mathrm{~mm}$ x 20mm; $1 \mathrm{~m}^{2}$ tela de nylon $3 \mathrm{~mm}$ x 2mm, torneira plástica, 01 metro de mangueira de 20mm de diâmetro, dois recipientes plásticos com capacidade de 20 litros, além de equipamentos para corte e acabamento do tambor. O Sistema foi abastecido com material orgânico vegetal proveniente do descarte doméstico diário e outros resíduos vegetais produzidos na propriedade. O estabelecimento do sistema de produção artificial proporcionou a manutenção natural do ciclo de vida da MSN, com a constante oviposição nas paredes internas do tambor. Além disso, a quantidade de larvas coletadas diariamente mostrou-se significativa (200g/dia). O mecanismo apresentou bom desempenho para a reciclagem de resíduos orgânicos e também para a produção de LMSN, sendo satisfatória a quantidade coletada diariamente.

Palavras-chave: Alimentação animal; Tecnologia de produção; Fonte alternativa de alimento.

\section{Resumen}

La innovación tecnológica en las zonas rurales, garantiza el mantenimiento y la subsistencia de los productores de dichas zonas. Es obligatorio utilizar estrategias encaminadas a reducir costos en la producción animal y minimizar el impacto ambiental. Por lo tanto, es necesario desarrollar métodos de producción alternativos a pequeña escala, que puedan implementarse en pequeñas propiedades con poca inversión de capital. En este sentido, el objetivo fue describir un sistema capaz de inducir la producción de larvas de mosca soldado negra-LMSN (Hermetia illucens) a través del atractivo de la puesta de huevos de adultos silvestres. Para realizar el sistema de producción de larvas se necesitó un bidón de plástico (200 litros); 10 metros de cuerda $(8 \mathrm{~mm}), 1,5 \mathrm{~m} 2$ de malla de alambre con malla de $25 \mathrm{~mm}$ x 20mm; $1 \mathrm{~m} 2$ de malla de nylon de $3 \mathrm{~mm}$ x $2 \mathrm{~mm}$, grifo de plástico, 01 metro de manguera de $20 \mathrm{~mm}$ de diámetro, dos recipientes de plástico con capacidad de 20 litros, además de equipo para corte y acabado del tambor. El Sistema se suministró con material vegetal orgánico procedente de la disposición diaria del hogar y otros residuos vegetales producidos en la propiedad. El establecimiento del sistema de producción artificial proporcionó el mantenimiento natural del ciclo de vida de MSN, con constante oviposición en las paredes internas del tambor. Además, la cantidad de larvas recolectadas diariamente fue significativa (200g/día). El mecanismo mostró un buen desempeño para el reciclaje de residuos orgánicos y también para la producción de LMSN, siendo satisfactoria la cantidad recolectada diariamente.

Palabras clave: Alimentación animal; Tecnología de producción; Fuente de alimentación alternativa.

\section{Introduction}

Insects have been proposed as an alternative source of high quality, efficient and sustainable protein. The use of these arthropods as a protein source can contribute to global food safety, through rations or as a direct food source for humans (Veldkamp et al., 2012).

The main species of edible insects used for commercial purposes are: common tenebrium (Tenebrio molitor), giant tenebrium (Zophobas morio), domestic cricket (Acheta domesticus), black cricket (Grillus assimilis), black soldier fly (Hermetia illucens) and the grasshopper (Locusta migratoria) (Nascimento et al., 2020) .

Among the various species of insects that have been studied for protein production puposes, the Hermetia illucens known as Black Soldier Fly (BSF) stands out in this scenario, for its capacity to convert organic residues into valuable biomass, with low release of greenhouse gas $(\mathrm{GHG})$, in addition to a low need for water consumption in its production (Nascimento et al., 2020; Mertenat et al., 2019 e Ermolaev et al., 2019).

Hermetia illucens L., belonging to the Stratiomyidae family, is native from the tropical and subtropical areas of the Americas. They are found in tropical and temperate climate regions, mainly in environments that contain decaying materials, which can come from plant residues, animal waste, and others (Diener et al., 2009; Tomberlin, 2001; Zhang et al., 2010). This fly develops better in warmer environments, especially in a temperature range between $29^{\circ} \mathrm{C}$ and $31^{\circ} \mathrm{C}$, and with a relative humidity (RH) between 50 and 70\%, and may require heating for its creation in colder places (Veldkamp et al., 2012).

Although they do not feed, adult insects are attracted by the odors of decaying organic matter, which represent an essential nutritional source for larvae from eggs deposited in strategic locations, always close to a food source (Diclaro \& Kaufman, 2009). The larvae of this insect are normally used in the decomposition and transformation of polluting organic 
waste into a valuable biomass, rich in protein and fat, which can be used in the production of biodiesel or as an alternative source of food for animals (Diener et al., 2011;Van Huis et al., 2013).

In the study by Finke, (2012), on the chemical composition of last instar larvae of this insect, results indicate levels of $49.6 \%$ and $39.7 \%$ of crude protein and crude fat, respectively. The carbohydrate content was small (2.3\%). The lauric acid content in larvae was determined in $45 \%$ of the total fatty acids. In another nutritional assessment study of these larvae carried out by Surendra et al. (2016) \& Jucker et al. (2017), indicated the presence of 42\% crude protein and 29\% lipid. The larvae of this insect presents itself as potential food for several animal species such as fish (Sogari et al., 2019), swines (Crosbie et al., 2020), birds (Lähteenmäki-uutela et al., 2017) among others.

The BSF reproduction for production of food larvae requires the assembly of a complex physical structure. One of the main difficulties faced by producers is to find an appropriate system for the cost-benefit of production. BSF's large-scale production scaled by Caruso (2014), consists in the construction of a solid structure of concrete and iron that requires a large capital investment, and takes place in two stages: The first is carried out in an insectary that consists on the generation of adults and eggs, while a second step is carried out in a larvae installation where the larvae are growing.

The production method adopted by Gougbedji et al. (2021), was performed using nylon cages measuring 75 x 75 x $115 \mathrm{~cm}$ (insectary). This location is used for rearing the winged insect and egg production. The rearing of larvae was carried out in plastic containers with size of $42 \times 29 \times 25 \mathrm{~cm}$, properly capped, with a side exit of pvc tube (50mm) for prepupae migration.

However, these traditional forms of production require the use of various physical structures that significantly increase production costs, making it impossible to use these methods in small production chains. Thus, it is necessary to develop new alternative methods of production aimed at small scales, being able to be implemented in small properties with little capital investment, contributing to the correct disposal of accumulated solid waste, in addition to reducing production costs with producer's rearing animals. In this sense, the aim was to describe the construction of a small-scale system capable of inducing the larvae production of the black soldier fly (H. illucens) through wild adults.

\section{Methodology}

The development of the BSF production project took place in the city of Jequitaí located in the north of the state of Minas Gerais, Brazil. Regarding the climate, the city comprises the Tropical Subhumid humid climate, closer to the limit of the Subhumid dry, characterized essentially by periods of rain concentrated between the months of October to March, on the other hand, the dry period occurs between the months of June to August (Nimer \& brandão, 1989).

To the confection of BSF Production System, the following materials were needed: a plastic drum, with capacity of 200 liters, 10 meters of $8 \mathrm{~mm}$ silk rope, $1.5 \mathrm{~m}^{2}$ wire mesh with $25 \mathrm{~mm}$ x 20mm mesh, $1 \mathrm{~m}^{2}$ nylon mesh $3 \mathrm{~mm}$ x $2 \mathrm{~mm}$, HERC brand plastic tap for slurry drainage, one meter of $20 \mathrm{~mm}$ diameter hose, two plastic containers with capacity of 20 liters for slurry collection and pre-pupae, in addition to equipment for cutting and finishing the drum (saw, metal saw, hammer, machetes, screws, sandpaper).

The system is relatively simple, however some precautions are necessary to achive its full potential and health. For its construction, a 200 liter plastic drum is used to conserve the organic waste used as larvae food (figure 1A). The drum cover was removed to form an opening, this opening is the entrance which makes it possible to place the waste in the drum, in addition to giving access to the adult BSF flies to lay their eggs on the inner walls of this container.

In the opening of the drum, a metallic screen with mesh of $25 \mathrm{~mm} \times 20 \mathrm{~mm}$ was placed (figure 1B); then, an opening of approximately $20 \mathrm{~cm}$ long and $5 \mathrm{~cm}$ wide is made in the drum, near the bottom of the lid (figure 1C) where pre-pupae in 
migratory phase will fall into a bucket of 20 liters for the collection when searching for a drier place, the entrance of this bucket was also protected by a metal screen (figures 1D and E).

To avoid the accumulation of liquids inside the drum, it was necessary to implement a particle filtration scheme, using a simple plastic faucet and a piece of $3 \mathrm{~mm} \times 2 \mathrm{~mm}$ nylon mesh, which works as a particulate filter that could potentially clog the slurry drainage scheme. This liquid is drained through the faucet and directed to a 20 liter plastic collection container positioned below the drum (figure $1 \mathrm{~F}$ and $\mathrm{G}$ ). Finally, an $8 \mathrm{~mm}$ rope must be used to secure the drum to a tree, avoiding contact with the ground (figure 1H). The drum was positioned at an angle of 25 degrees (figure 1A). The system was supplied with organic plant material from daily household disposal, in addition to other organic waste aggregated on the property, serving as a food source for black soldier flies. At the end of the constructive stages, the System followed as the model of (Figure 1).

Figure 1. Alternative system for small-scale production of Black Soldier Fly (Hermetia illucens).

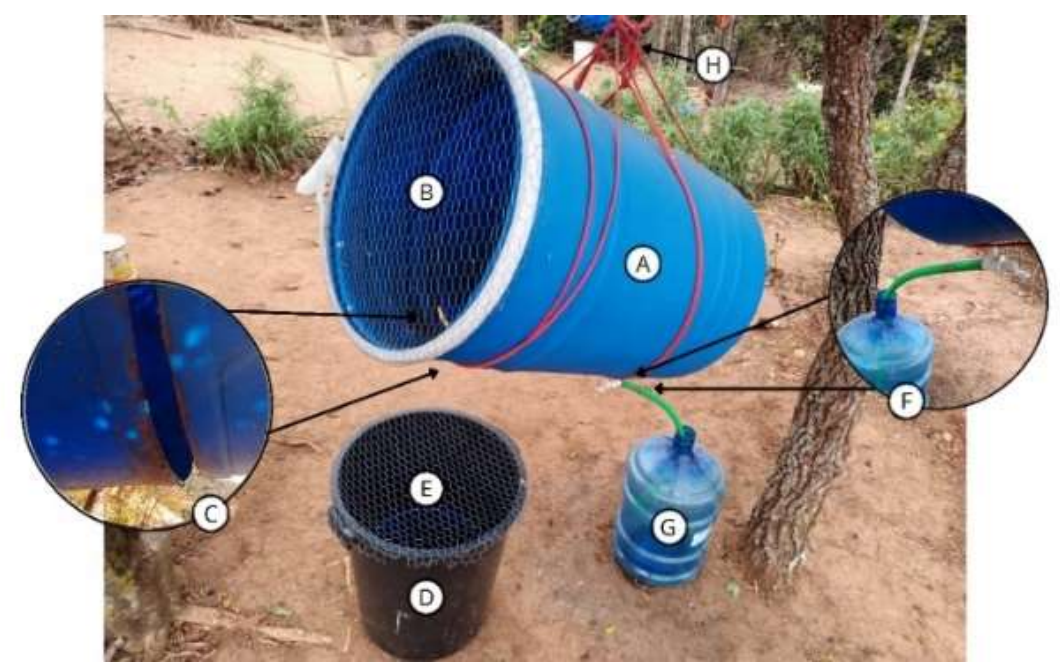

A: Drum; B: Wire mesh; C: Opening in the drum; D: Pre-pupae collection bucket; E: Wire mesh; F: Plastic faucet; G: Container for leachate collection; H: Silk rope. Source: Authors.

Figure 1 shows the final version of the black soldier fly larvae production system, after all construction steps have been completed. The letters represent each component of the system separately, and the arrows indicate where each integral part of the system has been placed.

\section{Results and Discussion}

The drum used in the system was 200 liters capacity, but its size can vary from 100 to 200 liters, depending on the availability and need of each producer. A $25 \mathrm{~mm}$ x $20 \mathrm{~mm}$ wire mesh was placed in the opening formed by the removal of the drum cover, in order to prevent predators such as birds, rodents and mammals from entering the system.

In order to impulse development results, the drum was positioned at a 25-degree angle, as the pupae are encouraged to migrate from the base of the drum until they reach the lower opening near the pool lid. According to Sheppard et al. (1994), and Diener et al. (2011), when BSF are in the pre-pupa stage, they instinctively tend to leave the substrate and look for a high, dry and clean location, this behavior is called "self-harvesting", an essential fact for the functioning of the system.

In the opening of the pupa collection container, a $25 \mathrm{~mm} \times 20 \mathrm{~mm}$ wire mesh was fixed to protect against predators. The by-product (slurry) generated in the System is drained through the tap at the bottom of the drum and directed to the collection bucket below the drum with the aid of a $20 \mathrm{~mm}$ diameter hose. This liquid, popularly known as slurry, is used for fertilizing various vegetables, since when incorporated into the soil it can improve its composition, acting as a fertilizer 
through the addition of nutrients and organic matter, increasing the capacity to retain moisture, exchange cations and microbial activity, and facilitating water absorption (Avancini et al.,2019).

The drum was placed suspended, anchored by an $8 \mathrm{~mm}$ rope to avoid any contact with the ground, thus hindering possible land invaders. According to Reguzzl et al. (2021), ants of the species Monomorium pharaonis (L.) can prey on eggs and newborn larvae of BSF.

BSF larvae are considered of high quality for food, and can be used in poultry, swine and fish farming (Makkar et al., 2014 \& Barragan et al., 2017), especially in regions that are socially vulnerable, reducing significant costs in animal production without interfering in the quality of the food provided. The installation of the artificial BSF production system provided the natural maintenance of its life cycle, with constant oviposition on the inner walls of the 200 liter drum, close to the waste and, consequently, obtaining larvae.

The development of this project has the potential to provide great social and economic viability, as it can be easily replicated and implemented in small rural properties for the treatment of organic waste. These are also known as biological waste, which most often includes food leftovers, which may be pre- or post-consumer (from homes, parks, gardens, restaurants, hotels, schools and markets for example), besides those from food and wood processing industries (Mertenat et al., 2019).

The essence of the implementation of this apparatus is directly linked to the concept of circular economy, this can be clarified having as a precept not only low cost, but also the action of constant movement of larvae on waste during feeding, which ensure aeration and aerobic conditions, thus having as a consequence the reduction in the emission of greenhouse gases (GHG). These, combined with other actions carried out by BSF, guarantee a sustainable cycle between humanity and environment (Mertenat et al., 2019).

Unlike the method by Sheppard et al. (2002), there is no use of cages in this one. However, the results obtained are satisfactory in terms of the amount of larvae collected daily (on average 200g/day) in each System, which can be used as an alternative food supplement for breeding animals (Figure 2).

Figure 2. Larvae produced daily as an alternative for animal feed.

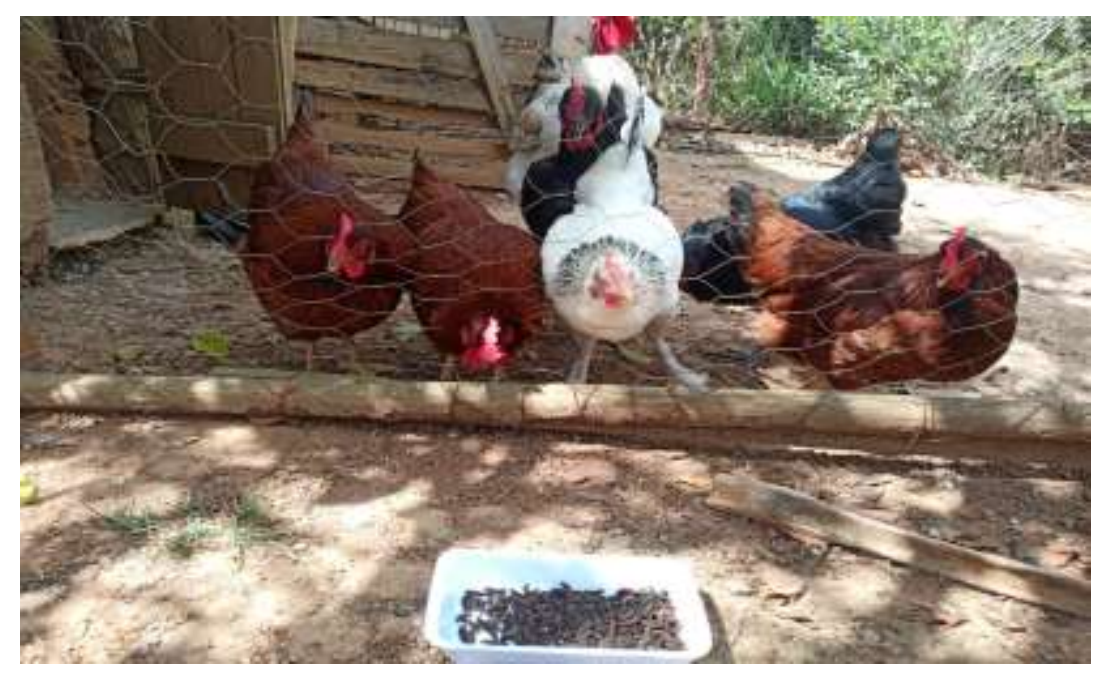

Source: Authors.

Figure 2 shows the black soldier fly larvae produced by the system, being supplied as an alternative food to free-range chickens raised on the property where the system was implemented. 
The production system has numerous advantages, however it has a limitation that is associated with climate change. In winter, with the arrival of low temperatures, there is a reduction in the amount of larvae collection, however, there is no cessation of production. The work developed by Chia et al. (2018) shows a BSF egg hatching rate of 80 and $75 \%$ at temperatures of 30 and $35^{\circ} \mathrm{C}$, respectively. At lower temperatures, however, the hatching rate decreased to less than $11 \%$ at $15^{\circ} \mathrm{C}$ and $59 \%$ at $20^{\circ} \mathrm{C}$. Also according to the author, the temperature with the highest pupae survival rate was $30^{\circ} \mathrm{C}$, with $77 \%$ relative humidity.

The mechanism also plays an important role in the cycling of organic materials, which will be converted into food for the larvae and biofertilizer. The latter can be used in agricultural activities, for example, in horticulture, aiming for the social and economic sustainability that the system offers, with low production cost, reduction of greenhouse gases and low emission of ammonia into the environment (Wang et al.,2017).

\section{Conclusion}

BSF's artificial larvae production mechanism showed good performance both for the recycling of organic waste and for the black soldier fly larvae production, with a satisfactory quantity collected daily, taking into account the cost-benefit of implementing the System. In addition, the System is viable for the correct destination and discard of organic plant material, offering an adequate destination for the generated by-products. But studies can be carried out to make better use of the system, such as, for example, testing other types of residues in larval development, in addition to physical improvements that can be made to increase the potential for producing larvae.

\section{Acknowledgments}

We would like to thank the Coordenadoria de Aperfeiçoamento do Pessoal de Nível Superior (CAPES), and the Universidade Federal de Minas Gerais-ICA (Institute of Agrarian Sciences) for all the support in the research.

\section{References}

Avancini, A. B., Matoso, E. S., Cerqueira, V. S., \& Silva, S. D. dos A. e. (2019). Caracterização química dos compostos líquidos oriundos da compostagem de resíduos agroenergéticos. Www.alice.cnptia.embrapa.br. http://www.alice.cnptia.embrapa.br/alice/handle/doc/1121019.

Barragan-Fonseca, K. B., Dicke, M., \& van Loon, J. J. A. (2017). Nutritional value of the black soldier fly (Hermetia illucens L.) and its suitability as animal feed - a review. Journal of Insects as Food and Feed, 3(2), 105-120. https://doi.org/10.3920/jiff2016.0055.

Canary, G.E., \& Gonzalez, L.D. (2012). Diseño y gestión de un proceso para reciclar desechos orgánicos con la Larva Hermetia Illucens para producir harina de larva.

Chia, S. Y., Tanga, C. M., Khamis, F. M., Mohamed, S. A., Salifu, D., Sevgan, S., Fiaboe, K. K. M., Niassy, S., van Loon, J. J. A., Dicke, M., \& Ekesi, S. (2018). Threshold temperatures and thermal requirements of black soldier fly Hermetia illucens: Implications for mass production. PLOS ONE, 13(11), e0206097. https://doi.org/10.1371/journal.pone.0206097.

Crosbie, M., Zhu, C., Shoveller, A. K., \& Lee-Anne, H. (2020). Standardized ileal digestible amino acids and net energy contents in full fat and defatted black soldier fly larvae meals (Hermetia illucens) fed to growing pigs. Translational Animal Science, 4(3). https://doi.org/10.1093/tas/txaa104.

Diclaro, J., \& Kaufman, P. (n.d.). Black Soldier Fly Hermetia illucens Linnaeus (Insecta: Diptera: Stratiomyidae) 1. Retrieved November 9, 2021, from https://edis.ifas.ufl.edu/pdf/IN/IN83000.pdf.

Diener, S., Solano, N. M.S., Gutiérrez, F.R., Zurbrügg, C., \& Tockner, K. (2011). Biological Treatment of Municipal Organic Waste using Black Soldier Fly Larvae. Waste and Biomass Valorization, 2(4), 357-363. https://doi.org/10.1007/s12649-011-9079-1.

Diener, S., Zurbrügg, C., \& Tockner, K. (2009). Conversion of organic material by black soldier fly larvae: establishing optimal feeding rates. Waste Management \& Research, 27(6), 603-610. https://doi.org/10.1177/0734242x09103838.

Ermolaev, E., Lalander, C., \& Vinnerås, B. (2019). Greenhouse gas emissions from small-scale fly larvae composting with Hermetia illucens. Waste Management, 96, 65-74. https://doi.org/10.1016/j.wasman.2019.07.011.

Finke, M. D. (2012). Complete Nutrient Content of Four Species of Feeder Insects. Zoo Biology, 32(1), 27-36. https://doi.org/10.1002/zoo21012. 
Gerland, P., Raftery, A. E., Sevčíková, H., Li, N., Gu, D., Spoorenberg, T., Alkema, L., Fosdick, B. K., Chunn, J., Lalic, N., Bay, G., Buettner, T., Heilig, G. K., \& Wilmoth, J. (2014). World population stabilization unlikely this century. Science, 346(6206), 234-237. https://doi.org/10.1126/science.1257469.

Lähteenmäki-Uutela, A., Grmelová, N., Hénault-Ethier, L., Deschamps, M.-H., Vandenberg, G. W., Zhao, A., Zhang, Y., Yang, B., \& Nemane, V. (2017). Insects as Food and Feed: Laws of the European Union, United States, Canada, Mexico, Australia, and China. European Food and Feed Law Review, 12(1), 22-36. https://www.jstor.org/stable/26451416.

Makkar, H. P. S., Tran, G., Heuzé, V., \& Ankers, P. (2014). State-of-the-art on use of insects as animal feed. Animal Feed Science and Technology, 197, 1-33. https://doi.org/10.1016/j.anifeedsci.2014.07.008.

Mertenat, A., Diener, S., \& Zurbrügg, C. (2019). Black Soldier Fly biowaste treatment - Assessment of global warming potential. Waste Management, 84, 173-181. https://doi.org/10.1016/j.wasman.2018.11.040.

Nascimento, A. F., Natel, A. S., Corsini, F. dos S., Madureira, E. R., \& Costa, D. V. (2020). Insetos: Alimento sustentável para nutrição animal (A. L. C. Silva, B. C. Góes, \& F. F. Putti, Eds.; $1^{\mathrm{a}}$ edição). ANAP.

Nimer, Edmon \& Brandão, A. M. P. M. (Org.). (1989). Balanço hídrico e clima da região dos Cerrados. Rio de Janeiro: IBGE.

Reguzzi, M. C., Cominelli, F., Bardone, M., Aldini, R. N., Chiesa, O., Panini, M., Casu, G., \& Mazzoni, E. (2021). Unwelcome guests at farms breeding the black soldier fly, Hermetia illucens (L.) (Diptera Stratiomyidae). Journal of Insects as Food and Feed, 1-6. https://doi.org/10.3920/jiff2021.0032.

Sheppard, D. C., Tomberlin, J. K., Joyce, J. A., Kiser, B. C., \& Sumner, S. M. (2002). Rearing Methods for the Black Soldier Fly (Diptera: Stratiomyidae): Table 1. Journal of Medical Entomology, 39(4), 695-698. https://doi.org/10.1603/0022-2585-39.4.695.

Sheppard, D.C., Newton, G.L., Thompson, S. A., \& Savage, S. (1994). A value added manure management system using the black soldier fly. Bioresource Technology, 50(3), 275-279. https://doi.org/10.1016/0960-8524(94)90102-3.

Sogari, G., Amato, M., Biasato, I., Chiesa, S., \& Gasco, L. (2019). The Potential Role of Insects as Feed: A Multi-Perspective Review. Animals, 9(4), 119. https://doi.org/10.3390/ani9040119.

Tomberlin, J. K., Sheppard, D. C., \& Joyce, J. A. (2002). Selected life history traits of black soldier fly rear on three artificial diets. J. Ento Sci, 37(4), 345-352. Van Huis, A., Van Itterbeeck, J., Klunder, H., Mertens, E., Halloran, A., Muir, G., \& Vantomme, P. (2013). Edible insects: future prospects for food and feed security. Food And Agriculture Organization Of The United Nations, Beaconsfield, Rome.

Van Zanten, H. H. E., Mollenhorst, H., Klootwijk, C. W., Van Middelaar, C. E., \& de Boer, I. J. M. (2015). Global food supply: land use efficiency of livestock systems. The International Journal of Life Cycle Assessment, 21(5), 747-758. https://doi.org/10.1007/s11367-015-0944-1.

Veldkamp, T., Van Duinkerken, G., van Huis, A., Lakemond, C. M. M., Ottevanger, E., Bosch, G., \& Van Boekel, T. (2012). Insects as a sustainable feed ingredient in pig and poultry diets: a feasibility study= Insecten als duurzame diervoedergrondstof in varkens-en pluimveevoeders: een haalbaarheidsstudie (No. 638). Wageningen UR Livestock Research.

Wang, Y.-S., \& Shelomi, M. (2017). Review of Black Soldier Fly (Hermetia illucens) as Animal Feed and Human Food. Foods, 6(10), 91. https://doi.org/10.3390/foods6100091.

Zhang, J., Huang, L., He, J., Tomberlin, J. K., Li, J., Lei, C., Sun, M., Liu, Z., \& Yu, Z. (2010). An Artificial Light Source Influences Mating and Oviposition of Black Soldier Flies, Hermetia illucens. Journal of Insect Science, 10(202), 1-7. https://doi.org/10.1673/031.010.20201. 